\title{
THE EFFECT OF ARTIFICIAL DEFOLIATION OF VARIOUS AGES OF LEAVES UPON WHITE PINE GROWTH ${ }^{1}$
}

\author{
By S. N. LINZON ${ }^{2}$
}

Received B.Sc.F. degree in 1948 from Faculty of Forestry, University of Toronto; M.A. degree in 1950 from Department of Botany, University of Toronto. Employed in the summers of 1945 and 1946 by the Kalamazoo Vegetable Parchment Co. Ltd., Espanola, Ontario, and in the summer of 1947 by the Great Lakes Paper Co., Fort William, Ontario. From 1948 to 1953 employed by the Division of Research, Ontario Department of Lands and Forests to work on forest pathology problems under the direction of the Department of Agriculture, Canada. In October, 1953, employment transferred directly to the Forest Pathology Laboratory, Maple, Ontario. Has conducted research work for the past several years in the determination of forest damage by atmospheric pollution in the Sudbury District and in the study of the nature and cause of white pine needle blight.

\section{ABSTRACT}

Foliage injuries produced by disease-causing organisms or adverse environmental influences may be confined to leaves of a specific age occurring among the "perennial" foliage of coniferous trees. Inadequate information exists concerning the effectiveness of leaves of different ages in promoting the growth of forest trees. An experiment was conducted to assess the effects of artificial removal of foliage of different ages from white pine trees upon height and diameter growth, subsequent axial development and foliage vigor. Although the observations show that all three ages of foliage are utilized in the growth of white pine, it is indicated that during the growing season the one-year-old foliage may be more important than the two-year-old foliage or foliage produced during the current year.

"Perennial" foliage of coniferous trees may consist of leaves developed in successive years during periods of two or more years. Spruce trees may retain leaves produced during six or seven successive years, but white pine normally possesses only three years' needles during the summer. In the autumn the oldest leaves are shed leaving the remaining foliage and terminal buds to overwinter. After the dormant season, new leaves are formed, and during the summer the coniferous tree bears its normal quota of different aged leaves.

\footnotetext{
${ }^{1}$ Contribution No. 393 from the Forest Biology Division, Science Service, Department of Agriculture, Ottawa, Canada. ${ }^{2}$ Forest Pathology Laboratory, Maple, Ontario.

\section{CAPTIONS FOR FACING PAGE}

Close-up of white pine saplings with different ages of foliage artificially removed. (Figs. 1-6) FIGURE 1: Current year's foliage removed.

FIGURE 2: One-year-old foliage removed.

FIGURE 3: Two-year-old foliage removed.

FIGURE 4: Current year's and 1-year-old foliage removed.

FIGURE 5: Current year's and 2-year-old foliage removed.

FIGURE 6: One-year-old and 2-year-old foliage removed.
} 
Healthy conifers usually possess a greater amount of foliage than is necessary for their maintenance. Small amounts of foliage injury may slightly affect the welfare of the tree, but severe harm or even death may result from extensive foliage injuries.

Different ages of foliage display injury symptoms when white pine trees are affected by a variety of diseases and environmental disturbances. Needle blight, a disease of unknown origin, affects the leaves of the current year only. Winter injury is apparent in the spring on the oldest needles. Sulphur fumes affect all ages of foliage, but due to an accumulation of sulphates in the perennial leaves over an extended period of time, the numbers of white pine displaying foliage injuries increase with increasing age of foliage. This increase in the numbers of affected trees in the Sudbury sulphur-fume area was most evident in the injuries sustained by the one-year-old foliage during the growing season (Linzon, 1954). The manifestation of injury on different ages of leaves focussed attention on a consideration of the importance of the needles of various ages upon the growth of white pine.

Belyea et al (1951) determined that white pine radial growth occurred between the middle of May and August 28 at Chalk River, Ontario, a period of approximately three and one-half months. "New" foliage of white pine is usually not fully grown until the middle of July, and thus may work effectively for the tree for approximately one and one-half months, while the two-year-old needles are probably declining in activity prior to autumnal discoloration and defoliation. Of the three sets of leaves on the white pine tree, it appears that the one-year-old foliage would be working most effectively during the entire growing season.

Correspondence with forest scientists and a review of the literature revealed that insufficient research had been conducted concerning the function and efficiency in plant growth of leaves of different ages.

Singh and Lal (1935) experimented with different aged leaves of flax, sugar cane, and wheat. They showed that the photosynthetic rate was slow for young leaves, increased to a maximum in mature leaves, and then decreased with age.

Freeland (1952) performed experiments on several coniferous tree species from July through October after the leaves of the current year were apparently mature. He found that the leaves of all the tree species investigated attained their maximum photosynthetic capacity approximately at the time of apparent leaf maturity during the first season of growth. The photosynthetic rate decreased with increasing age of foliage. Since there were no data for the spring or early summer, it was not possible to establish precisely when the peak of photosynthetic capacity was reached.

Farrar (1953) investigated the activity of red pine seedlings with the use of radioactive isotopes. He found that in general the one-year-old needles were most active, those of the current year less active, and the oldest least active. With cultures made in August when the current year's needles had ceased noticeable elongation, radioactivity in these needles was as great as in those one year older. 
Recently, Clark (1956) investigated the physiology of white spruce and balsam fir foliage in order to determine the immediate effects of defoliation by the spruce budworm. He showed that the "new" needles respired in excess of the assimilation rate of $\mathrm{CO}_{2}$ at first, but that the photosynthetic rate continued to increase during the summer and reached a maximum in late September. $\mathrm{He}$ found the rate of photosynthesis decreased with the age of foliage; the oneyear-old needles having a photosynthetic capacity of two and three times that found in six-year-old needles of balsam fir and white spruce, respectively.

In May, 1954, an experiment was conducted at Mattawa, Ontario, to assess the effects of completely removing leaves of different ages upon the subsequent height and diameter growth, bud formation, and foliage vigor of white pine trees. Fourteen healthy white pine trees, about six feet tall and 20 years old, were tagged and measured prior to defoliation. These young pines were selected from the same stand of trees growing on the same soil site. Seven groups of two trees each were subjected to various artificial defoliation tests (Figs. 1-6). Different ages of foliage were removed from the entire tree in each group as follows:

1. removal of the foliage of the current year only;

2. removal of the one-year-old foliage only;

3. removal of the two-year-old foliage only;

4. removal of both the foliage of the current year and the one-year-old foliage;

5. removal of both the foliage of the current year and the two-year-old foliage;

6. removal of both the one-year-old foliage and the two-year-old foliage; and

7. removal of no foliage on check trees.

Artificial defoliation of the test trees was not repeated after 1954. The defoliated trees were remeasured at the end of the growing seasons in September, 1954, and in September, 1955.

Table I and Fig. 7 were drawn up to record the changes in height and diameter growth of the test trees over the two growing seasons, 1954 and 1955. The growth made by these trees in 1954 represents the immediate effects of defoliation. The 1955 growth cannot be correlated directly with the defoliations made in 1954 since there would be a new arrangement of leaves on the trees in 1955. However, the growth made in 1955 is included to show the recovery made by the trees in the year following defoliation.

Examination of Table I and Fig. 7 reveals the following:

1. removal of the foliage of the current year only of white pine caused a marked decrease in height growth and a slight decrease in diameter growth in 1954, and there was a distinct recovery in both height and diameter growth in 1955;

2. removal of only the one-year-old foliage caused a slight decrease in both height and diameter growth in 1954 and there was little change in 1955;

3. removal of only the two-year-old foliage caused a slight decrease in both beight and diameter growth in 1954 and there was good diameter growth recovery in 1955; 
TABLE I

Efpect of Artificial Defoliation upon White Pine Growth at Mattawa, Ontario

\begin{tabular}{|c|c|c|c|c|c|c|c|}
\hline 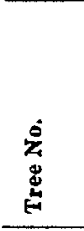 & 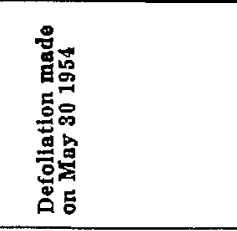 & 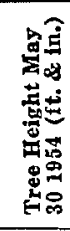 & 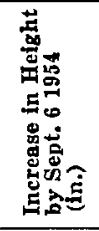 & 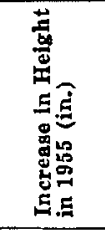 & 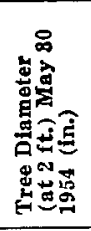 & 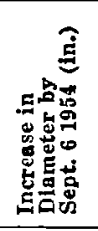 & 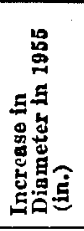 \\
\hline 5301 & $\begin{array}{l}\text { Removal of } \\
\text { current year's }\end{array}$ & 5 & 2.0 & 7.25 & 0.8 & 0.00 & 0.17 \\
\hline 5302 & foliage & 5 & 4.5 & 13.13 & 0.8 & 0.10 & 0.10 \\
\hline 5303 & $\begin{array}{l}\text { Removal of } \\
1 \text {-year-old }\end{array}$ & 6 & 9.0 & 8.00 & 1.0 & 0.10 & 0.07 \\
\hline 5304 & foliage & 6 & 7.0 & 6.75 & 0.8 & 0.03 & 0.12 \\
\hline 5305 & $\begin{array}{l}\text { Removal of } \\
\text { 2-year-old }\end{array}$ & 51 & 8.3 & 6.85 & 0.8 & 0.03 & 0.10 \\
\hline 5306 & foliage & 51 & 7.8 & 5.85 & 1.0 & 0.10 & 0.14 \\
\hline 5307 & $\begin{array}{l}\text { Removal of } \\
\text { current year's } \\
\text { and 1-year-old }\end{array}$ & 6 & 1.0 & 5.63 & 0.9 & 0.03 & 0.01 \\
\hline 5308 & foliage & 6 & 2.8 & 4.85 & 1.0 & 0.00 & 0.06 \\
\hline 5309 & $\begin{array}{l}\text { Removal of } \\
\text { current year's } \\
\text { and 2-year-old }\end{array}$ & 7 & 2.2 & 8.00 & 1.1 & 0.13 & 0.07 \\
\hline 5310 & foliage & 7 & 4.8 & 7.85 & 0.9 & 0.23 & 0.02 \\
\hline 5311 & $\begin{array}{l}\text { Removal of } \\
1 \text {-year-old } \\
\text { and } 2 \text {-year-old }\end{array}$ & 51 & 3.8 & 4.50 & 0.9 & 0.03 & 0.07 \\
\hline 5312 & foliage & 51 & 6.3 & 3.85 & 1.1 & 0.00 & 0.17 \\
\hline 5313 & $\begin{array}{l}\text { No foliage } \\
\text { removed on }\end{array}$ & 7 & 16.1 & 12.50 & 1.3 & 0.13 & 0.20 \\
\hline 5314 & Check trees & 7 & 18.4 & 10.62 & 1.0 & 0.10 & 0.19 \\
\hline
\end{tabular}

4. removal of both the foliage of the current year and the one-year-old foliage caused a severe decrease in both height and diameter growth in 1954 and there was good height growth recovery in 1955;

5. removal of both the foliage of the current year and the two-year-old foliage caused a severe decrease in height growth and no decrease in diameter growth in 1954 and there was excellent height growth recovery and decreased diameter growth in 1955; 


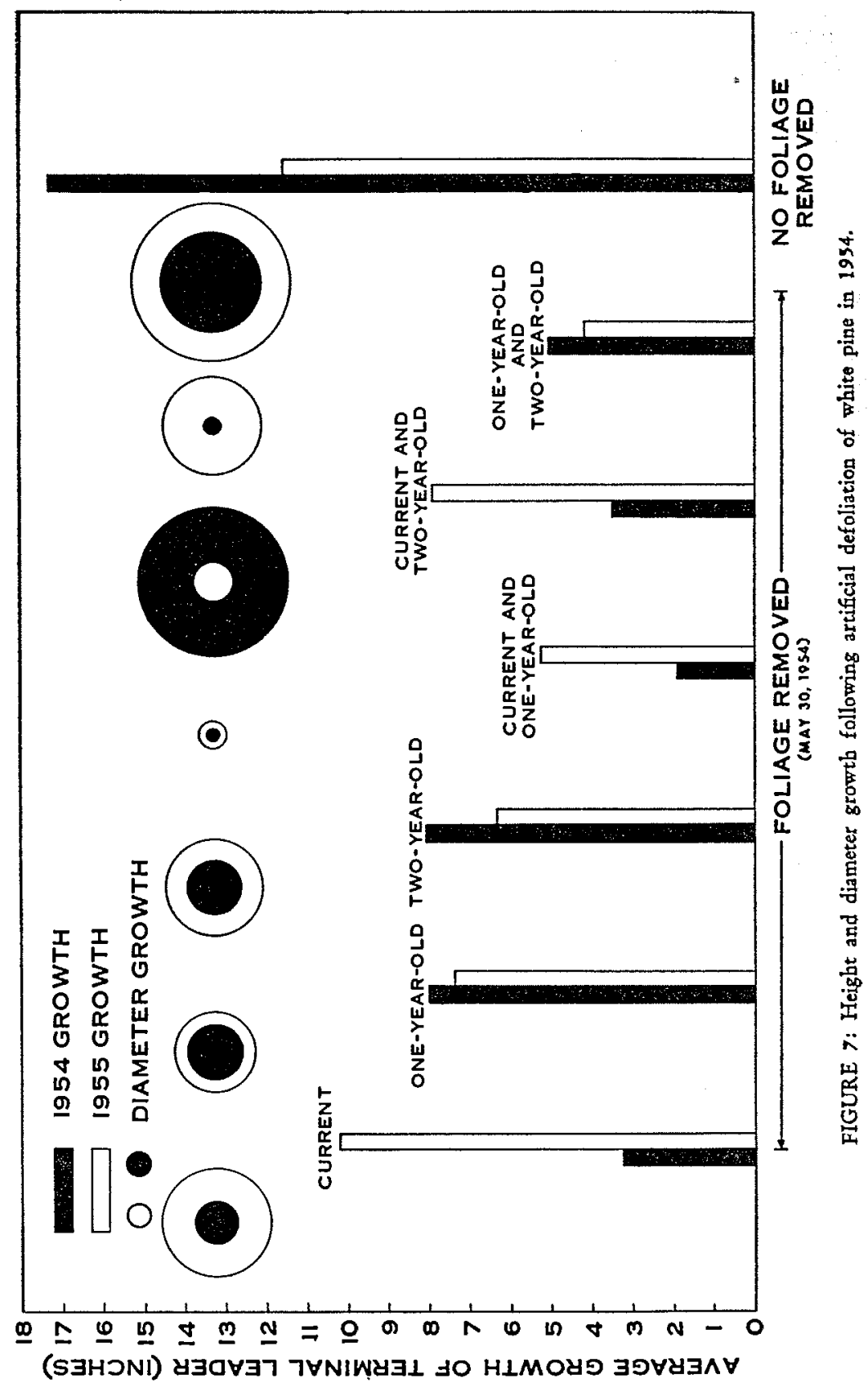


6. removal of both the one-year-old foliage and the two-year-old foliage caused a severe decrease in both height and diameter growth in 1954 and there was good diameter growth recovery in 1955;

7. removal of no foliage on the check trees made their normal growth in height and diameter to appear exceptional in both 1954 and 1955 when compared with the defoliated trees.

\section{CONCLUSIONS}

The growth responses following artificial defoliation of white pine trees indicated that the removal of any year's foliage had an effect on height growth. Diameter growth was severely reduced in those trees which had their one-yearold foliage removed in combination with another year's foliage. It is evident that all ages of foliage are of value to the white pine tree, but it is indicated that the one-year-old foliage may be the most important. It is desirable that further investigations be conducted on the function and efficiency of various ages of needles in the growth of coniferous trees.

\section{REFERENCES}

1. BELYEA, R. M., D. A. FRASER, and A. H. ROSE. 1951. Seasonal growth of some trees in Ontario. For. Chron. 27 (4)

2. CLARK, J. 1956. Photosynthesis of white spruce and balsam fir. Can. Dept. Agr. Bi-monthly Pro. Rpt. 12(5).

3. FARRAR, J. L. 1953. Distribution of radiophosphorus in red pine seedlings. Silvic Lft. No. 78. Dept. Res. and Dev., Ottawa.

4. FREELAND, R. O. 1952. Effect of age of leaves upon the rate of photosynthesis in some conifers. Pl. Phys. 27: 685-690.

5. LINZON, S. N. 1954. Comparison of white pine growth habits in the Sudbury and surrounding districts of Ontario in 1953. Can. Dept. Agr., Sci. Serv., For. Biol. Div., Maple, Ont. Mimeo. Rept.

6. SINGH, B. N. and K. N. LAL. 1935. Investigations of the effect of age on assimilation of leaves. Ann. Bot. 49: 291-307. 